\title{
Growth and Yield of Some Jew's Mallow (Corchorus olitorius L.) Ecotypes as Affected by Planting Dates and Foliar Application of Gibberellic and Humic Acids
}

\begin{abstract}
Haridy, A.G.; H.S. Abbas and A.A. Mousa
Department of Vegetables, Faculty of Agriculture, Assiut University, Assiut, Egypt

E-mail: ashrafharidy@aun.edu.eg

Received on: $15 / 1 / 2019$

Accepted for publication on: 21/1/2019

\section{Abstract:}

A Field experiment was conducted in 2015 and 2016 cropping seasons at the Vegetable Crops Research Station, Faculty of Agriculture, Assiut University, to study the response of three Jew's Mallow Ecotypess (Assiut, Eskandarany and Aswan) to planting dates and foliar application of Gibberellic acid (GA3) and Humic acids (HA) treatments. The Jew's Mallow ecotypes were planted on $15^{\text {th }}$ Feb. and $15^{\text {th }}$ Oct. in both cropping seasons and subjected to three foliar applications of $0.25 \mathrm{mg} .1^{-1} \mathrm{GA}_{3}$ (T1), $0.5 \mathrm{mg} . \mathrm{l}^{-1} \mathrm{HA}$ (T2) and $0.5 \mathrm{mg} . \mathrm{l}^{-1} \mathrm{HA}+0.25 \mathrm{mg} . \mathrm{l}^{-1}$ $\mathrm{GA}_{3}$ (T3) and untreated plants were used as control. The results revealed that the Jew's Mallow ecotype 'Assiut' attained the highest plant $(\mathrm{cm})$, number of leaves/plant, weight of leaves/plant $(\mathrm{g})$, weight of plant $(\mathrm{g})$, percentage net weight of leaves/plant and foliage yield $\left(\mathrm{kg}^{\mathrm{p}} \mathrm{plot}^{-1}\right)$ in both seasons. The early planting date (15 Feb.) extremely increased growth, yield components and yield parameters in 2015 and 2016. Foliar application of gibberellic acid $\left(\mathrm{GA}_{3}\right)$ at $0.25 \mathrm{mgl}^{-1}$ (T1) significantly increased growth and yield of Jew's Mallow plants. Spraying plants of the Jew's Mallow ecotype 'Assiut' with $\mathrm{GA}_{3}$ at $0.25 \mathrm{mg} . \mathrm{l}^{-1}$ at planting date $15^{\text {th }}$ Feb. significantly increased growth, yield components and yield parameters in both seasons.
\end{abstract}

Keywords: Jew's Mallow, GA3, Humic acid, planting dates, foliar spraying, Ecotypess.

\section{Introduction}

Jew's Mallow (Corchorus olitorius L.), sometimes known as Jute Mallow, is one of the most important leafy vegetable in tropical areas including Egypt. Egypt cultivated about 887 ha jew's mallow and produced about 2173 tons with a productivity of 2.4499 ton/ha (FAO, 2016). Jew's mallow is considered as one of the most important vegetables bringing daily cash for smallholders and poor families in Egypt particularly Upper Egypt. However, less attention was paid by researches to conduct studies for improving the crop growth, yield, quality and nutritional values. Recently, Jew's Mallow as a Neglected and Underutilized crop Species (NUS) received great international recognition because of its role in providing food and nutrition security and income opportunities among smallholder farmers. Also, the NUS crops can be utilized to adapt agriculture and food systems to climate change. Egyptian farmers with particular to Upper Egypt farmers (smallholders) grew Jew's Mallow in many marginal areas for their livelihoods. They use their own seeds which consequently result in genetic erosion and low yield and quality due to low fertility soil, add no fertilizers, pest and diseases (Abdallah et al., 2010; Rashwan, 2011). Cultivating Jew's Mal- 
low in marginal areas without adding either any fertilizers/small amounts to the soil (organic and/or inorganic fertilizers) or to the plants (foliar application of fertilizers) caused great reduction in crop yield and quality (Ogunrindé and Fasinmirin, 2011). Suitable planting dates of vegetables increases growth and yield without adding extra production costs. Jew's mallow is a short-day plant and grows well at high humidity and a temperature range $25-35^{\circ} \mathrm{C}$ (Vincent and Yamaguchi, 1997). Low temperature and short day promote plant flowering at early growth stage and reduce vegetative growth. In Egypt, It was reported that late planting dates $\left(1^{\text {st }}\right.$ June) increased vegetative growth, yield components, yield and chemical constituents, while reduced the percentage of net leaves weight as compared with planting dates $1^{\text {st }}$ of April and $1^{\text {st }}$ of May. (Wahba et al., 2003; Abd-Allah and Nasr, 2005). Foliar application of fertilizers is a promised alternative source of fertilizers that expected to enhances crop yield and quality. Gibberellic acid $\left(\mathrm{GA}_{3}\right)$ is a phytohormone caused extremely acceleration for plant growth and development when applied at low concentrations. Plant Acceleration occurred when growth regulators like $\mathrm{GA}_{3}$ exogenously applied in proper concentration at a proper time in a specific crop (Saini et al., 2017). $\mathrm{GA}_{3}$ play significant roles in plant growth and development including enhances growth activities to plant (Saini et al., 2017), stimulates stem elongation (Lee, 1990), and increases dry weight and yield (Deotale et al., 1998 and Maske et al., 1998). Humic acid (HA) is a bio-fertilizer can be extracted from any materials containing welldecomposed organic matter like soil, coal, compost, etc. Manipulation and preparation of Humic acid can be simply conduct using a solution of sodium hydroxide which causes much dissolves of the organic matter. ph of the humic solution can be adjusted to 2 using acids. The organic material will begin to flocculate and can be separated from the liquid portion (Kussow, 2002). Humic material can be added to the soil as ground fertilizers to ameliorate soil constructing and ground microorganisms. Ghabbour and Davies, (2001) reported that adding humic material to the soil decreasing the unfavorable effects of chemical fertilizers on the ground and reign a major effect on plant growth. On the other hand, Humic materials can be successfully sprayed over the plants to elevate plant growth, yield and quality (Yildirim, 2011). There were a limited information about the effects of growth regulators like $\mathrm{GA}_{3}$ and organic products like HA on growth, yield and quality of leafy vegetables with particular Jew's Mallow at different planting dates. The presented work aimed to study growth and yield response of three Jew's Mallow ecotypes to planting dates and application of Humic acid (HA) and gibberellic acid $\left(\mathrm{GA}_{3}\right)$.

\section{Materials and Methods Plant Materials}

The genetic materials of jew's mallow were three ecotypess called 'Eskandarany', 'Balady Aswan' and 'Balady Assiut' (Obatined from Local Agricultural markets in Alexandria, Aswan and Assiut governorate, respectively.). Germination test was 
conducted in the laboratory of vegetable crops to test seeds viability.

\section{Experimental site and design}

A Field experiment was conducted at the Vegetable Crops Research Station, Faculty of Agriculture, Assiut University, Egypt, during 2015 and 2016. Main soil physical and chemical proprieties were as follow: soil texture clay, $\mathrm{pH} 8$, field capacity $42 \%$, available phosphorus $0.01 \%$ and total nitrogen $0.08 \%$. The experiment was laid out in split plot following in randomized complete block design (RCBD) with 3 replicates. The Jew's mallow ecotypes were in the main plots, while $\mathrm{GA}_{3}$ and HA treatments were in the sub plots.

Soil preparation, planting and Agriculture Practices

The experimental site was plowed 3 perpendicular times 2 months before planting. Two weeks before planting the site was well leveled and divided into plots each of $3 \mathrm{~m} \times 3 \mathrm{~m}$. Seeds of jew's mallow cultivars were planted in $15^{\text {th }}$ Feb. and $15^{\text {th }}$ Oct. 2015 and 2016. Seeds of all jew's mallow ecotypes were planted in rows with planting space $20 \mathrm{~cm}$ between row and $10 \mathrm{~cm}$ between plants. Cultural practices (irrigation, fertilization and pests and diseases control) were applied as recommended for jew's mallow production (Abd-Allah, 2006).

Gibberellic $\left(\mathrm{GA}_{3}\right)$ and Humic acid (HA)Treatments.

The Humic acid (24\%) and Gibberellic acid (35\%) were used as plant stimulants to enhance plant growth and subsequently foliage yield. The following treatments of
Humic and Gebrillic acids were foliar sprayed after 30 days from sowing:

1. Control: plants received niether HA nor $\mathrm{GA}_{3}$ treatments

2. HA: foliar application of HA at $0.5 \mathrm{mg} .1^{-1}$

3. $\mathrm{GA}_{3}$ : foliar application of $\mathrm{GA}_{3}$ at $0.25 \mathrm{mg} .1^{-1}$

4. $\mathrm{HA}+\mathrm{GA}_{3}$ : foliar application of Humic acid and $\mathrm{GA}_{3}$ combination at $0.5 \mathrm{mg} .1^{-1}$ (HA) and $0.25 \mathrm{mg} .1^{-1} \mathrm{GA}_{3}$. Measurments

The following parameters were measured using 20 randomly taken plants per/plot: plant height $(\mathrm{cm})$, plant weight $(\mathrm{g})$, number of leaves/ plant, leaves weight $(\mathrm{g})$, percentage net weight of fresh leaves per plant $=$ leaves weight per plant (g) / plant weight $(\mathrm{g}) \times 100$ and total foliage yield per plot was recorded in $\mathrm{kg}$ per plot as the total weight of plants in each plot.

\section{Statistical procedures:}

The data were subjected to combined analysis over year using model analysis (Gomez and Gomez, 1984). Before combining the data single analysis of variance for each year was conducted to test normal distribution of the data and variances homogeneity (Gomez and Gomez, 1984). Analysis of variance was conducted using the Statistical Analysis System (SAS) program (ver. 9.00, SAS Institute, Cary, NC, USA). The treatment means were compared by $\mathrm{F}$ test and using Duncan"s New multiple range test (Steel and Torrie 1982).

\section{Results and Discussion}

There were significant differences due to planting dates, Jew's Mallow ecotypes, Humic (HA) and Gibberellic $\left(\mathrm{GA}_{3}\right)$ acids and their interaction for all measured parameters. 


\section{Plant height (cm)}

Plant height of tested Jew's Mallow ecotypes were significantly affected by planting dates and foliar spray treatments (Table 1). The tallest plant were measured for plants of the ecotypes 'Assiut' with lengths 79.18 $\mathrm{cm}\left(15^{\text {th }}\right.$ Feb. 2105), $73.98 \mathrm{~cm}\left(15^{\text {th }}\right.$ Oct 2015), $81.67 \mathrm{~cm}\left(15^{\text {th }}\right.$ Feb. 2016) and $75.33 \mathrm{~cm}\left(15^{\text {th }}\right.$ Oct 2016). The shortest plants were produced by 'Eskandarany' in both planting dates in 2015 and 2016 (Table 1). Regarding effects of foliar application of $\mathrm{GA}_{3}$ and $\mathrm{HA}$, the results revealed that foliar application of $\mathrm{GA}_{3}$ at $0.25 \mathrm{mg}$ $1^{-1}$ increased plant height by $39.63 \%$ $\left(15^{\text {th }} \mathrm{Feb} 2015\right), 54.62 \%$ (15 $5^{\text {th }}$ Oct. $2015), 63.66 \%\left(15^{\text {th }}\right.$ Feb 2016) and $49.41 \%\left(15^{\text {th }}\right.$ Oct 2016$)$ as compared to the control (untreated plots). Regardless planting dates and ecotypes, the least plant height was observed for the untreated plots (control treatment). Planting the Jew's Mallow on $15^{\text {th }}$ Feb significantly increased plant height in 2015 and 2016 (Table 1). Concerning interaction, spraying Jew's Mallow ecotypes 'Assiut' with $\mathrm{GA}_{3}$ at $0.25 \mathrm{mg} \mathrm{l}^{-1}$ result the longest plant with $90.55 \mathrm{~cm}$ and $92.67 \mathrm{~cm}$ for planting dates $15^{\text {th }}$ Feb 2015 and 2016, respectively. The control treatment of ecotypes 'Aswan' produced the shortest plants with the late planting date $15^{\text {th }}$ Oct in 2015 and 2016 (Table 1). Gibberellic acid $\left(\mathrm{GA}_{3}\right)$ as a phytohormone accelerate plant growth and development when it exogenously applied at low concentrations (Saini et al., 2017). Time of application, method of application and $\mathrm{GA}_{3}$ concentrations critically controls the roles and motivations of $\mathrm{GA}_{3}$ in plant growth and develop- ment. For instance, application of $\mathrm{GA}_{3}$ at proper concentration and time was reported to stimulate stem elongation (Lee, 1990), and increases dry weight and yield (Deotale et al., 1998 and Maske et al., 1998). There were limited information and researches considered the effects of $\mathrm{GA}_{3}$ and Humic acid (HA) on growth and developed of Jew's Mallow. However, in Indian mustard, Sani et al., (2017) reported that foliar application of $\mathrm{GA}_{3}$ at $125 \mathrm{ppm}$ resulted in maximum plant height $(190.44 \mathrm{~cm})$ at maturity stage, followed by foliar sprayed of $\mathrm{GA}_{3}$ at $90 \mathrm{ppm}(188.33$ $\mathrm{cm})$ over control $(180.55 \mathrm{~cm})$. Spraying $\mathrm{GA}_{3}$ significantly increased plant height of mungbeen at 40 days after sowing $(38.57 \mathrm{~cm})$ and 50 days after sowing $(45.65 \mathrm{~cm})$ as compared with biofertilizers and control treatments (Lee et al., 1990). Moreover, the authoers found that $\mathrm{GA}_{3}$ significantly increased plant height of the mungbeen variety 'Barimoog-2' at 40 days after sowing $(40.53 \mathrm{~cm})$ and 50 days after sowing $(47.27 \mathrm{~cm})$. Foliar application of Humic acid (HA) affected plant height of canola and maximum heights were obtained using $\mathrm{HA}$ at concentration of $2 \%$, while shortest plants were observed under control treatments (Sani, 2014). Humic acid also significantly increased plant height of mustard (Rajpar et al., 2012), tomato and cucumber (Atiyeh et al., 2002) and peppers (Arancon et al., 2006).

\section{Weight of plant (g)}

The results showed that, the early planting date $\left(15^{\text {th }}\right.$ Feb.) extremely increased plant weights of all tested ecotypes as compared to late planting date $\left(15^{\text {th }}\right.$ Oct.) in 2015 and 
2016. Plants of the Jew's Mallow ecotypes 'Assiut' recorded the highest weight in both planting dates as compared with other tested ecotypes. However, the early planting $\left(15^{\text {th }}\right.$ Feb) of ecotypes 'Assiut' extremely increased plants weight in 2015 and 2016 (Table 2). The maximum plant weights of ecotypes 'Assiut' were $76.59 \mathrm{~g}\left(15^{\text {th }}\right.$ Feb 2015), 74.34g $\left(15^{\text {th }}\right.$ Feb 2016), 68.93g (15 ${ }^{\text {th }}$ Oct 2015) and $71.54 \mathrm{~g}\left(15^{\text {th }}\right.$ Oct 2016$)$ Contrary, the least plant weight was observed for ecotypes 'Aswan' in late planting $\left(15^{\text {th }}\right.$ Oct $)$ in both seasons. Regarding effects of $\mathrm{GA}_{3}$ and HA foliar spraying on plant weight of Jew's Mallow ecotypes, the results illustrated that spraying $\mathrm{GA}_{3}$ at $0.25 \mathrm{mg} . \mathrm{l}^{-1}$ significantly increased plants weight in late $\left(15^{\text {th }}\right.$ Oct $)$ and early planting $\left(15^{\text {th }}\right.$ Feb) in 2015 and 2016. In addition $\mathrm{HA}$ in combination with $\mathrm{GA}_{3}(0.5$ mg. $.^{-1} \mathrm{HA}+0.25 \mathrm{mg} . \mathrm{l}^{-1} \mathrm{GA}_{3}$ ) in early planting $\left(15^{\text {th }} \mathrm{Feb}\right.$.) increased weight of Jew's Mallow plants (Table 2). The control treatment (without $\mathrm{GA}_{3}$ and HA applications) produced the least plants weight $(\mathrm{g})$ in late and early planting dates in both seasons. A significant interaction was observed between Jew's Mallow ecotypes, planting dates and foliar application of $\mathrm{GA}_{3}$ and $\mathrm{HA}$ with regard weight of plant $(\mathrm{g})$. Spraying plants of ecotypes 'Assiut' with $\mathrm{GA}_{3}$ at $0.25 \mathrm{mg}^{-1}$ at early planting date $\left(15^{\text {th }}\right.$ Feb) in 2015 result the highest weight of plants $(95.37 \mathrm{~g})$, followed by application $\mathrm{GA}_{3}$ at $0.25 \mathrm{mg}^{-1}$ at early planting date $\left(15^{\text {th }} \mathrm{Feb}\right)$ of ecotypes Assiut' in 2016 with $93.35 \mathrm{~g}$ and spraying ecotypes 'Assiut' with a combination of $\mathrm{GA}_{3}$ at $0.25 \mathrm{mg} .1^{-1}+\mathrm{HA}$ at 0.5 mg. $1^{-1}$ at early planting date $\left(15^{\text {th }} \mathrm{Feb}\right)$ in 2016 (Table 2). Oppositely, the least weight of plant $(\mathrm{g})$ was observed at late planting $\left(15^{\text {th }} \mathrm{Oct}\right)$ of ecotypes 'Eskandarany' in 2015 and 2016. There were limited information and researches considered the effects of $\mathrm{GA}_{3}$ and Humic acid (HA) on growth and developed of Jew's Mallow. However, Indian mustered growth and yield was significantly affected by $\mathrm{GA}_{3}$ application (Sani et al., 2017). They reported that all $\mathrm{GA}_{3}$ treatments significantly increased plant dry biomass as compared to the control treatment. Foliar application of $\mathrm{GA}_{3}$ enhanced growth and yield of Cabbage (Akand, et al., 2015); Tomato (Kumar et al., 2014), strawberry (Jamal et al., 2012) and indian mustard (Sani et al., 2017). Moreover, humic acid significantly affected growth and yield of varied number of crops including Canola (Sani, 2014); Tomato (Abdellatif et al., 2017); Garlic (Abdel Razzak and El-SHarkawy, 2013). On the other hand, Jew's mallow is a short-day plant and grows well at high humidity and a temperature range $25-35^{\circ} \mathrm{C}$ (Vincent and Yamaguchi, 1997). Low temperature and short day promote plant flowering at early growth stage and reduce vegetative growth. In Egypt, It was reported that late planting dates $\left(1^{\text {st }}\right.$ June) increased vegetative growth, yield components, yield and chemical constituents, while reduced the percentage of net leaves weight as compared with planting dates $1^{\text {st }}$ of April and $1^{\text {st }}$ of May. (Wahba et al. 2003; Abd-Allah and Nasr 2005).

Number of leaves/plant

Planting Jew's Mallow at $15^{\text {th }}$ Feb in both seasons result the highest number of leaves/plant as compared 
to planting date $15^{\text {th }}$ Oct. The ecotypes 'Assiut' produced the maximum number of leaves/plant in 2015 and 2016, followed by the ecotypes 'Eskandarany', while the ecotypes 'Aswan' produced the least number of leaves/plan. Spraying $\mathrm{GA}_{3}$ at $0.25 \mathrm{mg} .1^{-1}$ significantly increased number of leaves/plant, while the control treatment (without application of $\mathrm{GA}_{3}$ and HA) revealed the least number of leaves/plant (Table 3). Regarding interaction the results illustrated that spraying plants of the ecotypes 'Assiut' at early planting date $\left(15^{\text {th }}\right.$ Feb 2015$)$ by $\mathrm{GA}_{3}$ at $0.25 \mathrm{mg} .1^{-1}$ result the highest number of leaves per plant (70.08). As presented in Table (3), the least no. of leaves/plant was observed for plants of ecotypess 'Aswan' (22.40) and 'Eskandarany' (22.70) under late planting $\left(15^{\text {th }}\right.$ Oct 2016) and without application of $\mathrm{GA}_{3}$ and HA (control treatment). Tsiakaras et al. (2014) investigated the effects of nitrogen application rate and gibberellic acid $\left(\mathrm{GA}_{3}\right)$ on yield and earliness of production and marketability of lettuce. They observed that $\mathrm{GA}_{3}$ and high nitrogen rates significantly increased total number of leaves per plant. Application of $\mathrm{GA}_{3}$ at $75 \mathrm{ppm}$ result in the highest no. of leaves/plant (21.04 leaf/plant), while the minimum no. of leaves/plant (7.13) was noted at control treatment (Roy and nasiruddin, 2011). Number of leaves per plant varied significantly at different days after transplanting (DAT) due to application of different concentrations of $\mathrm{GA}_{3}$. The maximum leaves per plant (15.05) was observed in $\mathrm{GA}_{3}(90 \mathrm{ppm})$ and the minimum (11.47) was found from $\mathrm{GA}_{3}(0.0 \mathrm{ppm})$ at 60 days after sow- ing (Kairul Mazed, 2015). In Egypt, it was reported that late planting of Jew's Mallow ( $1^{\text {st }}$ June) significantly reduced percentage of net weight of plant leaves due to high temperature and day length (Wahba et al. 2003; Abd-Allah and Nasr 2005). In addition, Rashwan (2011) found that planting Jew's Mallow ecotypess on April $25^{\text {th }}$ result the highest plant heights, foliar yield and fresh and dry mass of plants. In Egypt highest fresh leafy yield of Jew's Mallow ecotypess was obtained with planting dates mid May and mid April (AbdAllah et al., 2010).

\section{Weight of leaves/plant (g)}

The sowing dates $15^{\text {th }}$ Feb in 2015 and 2016 revealed the highest weight of leaves/plant as compared to the planting dates $15^{\text {th }}$ Oct. in both seasons. The Jew's Mallow ecotypes were significantly varied with regard weight of leaves/plant (g). The ecotypes 'Assiut' produced the highest weight of leaves/plant with 32.45 , $34.65,25.59$ and 24.28 (g) for planting dates $15^{\text {th }}$ Feb. 2015, $15^{\text {th }}$ Feb. 2016, $15^{\text {th }}$ Oct. 2015 and $15^{\text {th }}$ Oct. 2016, respectively (Table 3 ). Foliar application of $\mathrm{GA}_{3}$ at $0.25 \mathrm{mg} . \mathrm{l}^{-1}$ result highest weight of leaves/plant in both seasons, followed by combination of $\mathrm{GA}_{3}$ at $0.25 \mathrm{mg} . \mathrm{l}^{-1}+\mathrm{HA}$ at 0.5 mg. $1^{-1}$, while control treatment (without foliar application of $\mathrm{GA}_{3}$ and HA) recorded the least weight of leaves/plan. A significant interaction was observed between planting dates, Jew's Mallow ecotypes and foliar spray treatments. Sowing the ecotypes 'Assiut' on $15^{\text {th }}$ Feb. in 2015 and 2016 and spraying the plants with $\mathrm{GA}_{3}$ at $0.25 \mathrm{mg} .1^{-1}$ result the highest weight of leaves/plant (45.86 and 
$50.00(\mathrm{~g})$ for sowing dates $15^{\text {th }}$ Feb. in 2015 and 2016, respectively, Table 3 ). The control treatment (without spraying $\mathrm{GA}_{3}$ and $\mathrm{HA}$ ) recorded the least weigh of leaves/plant for the ecotypess 'Eskandarany' and 'Aswan' on planting dates $15^{\text {th }}$ Oct. 2015 and 2016. Tovihoudji et al., (2015) evaluated the application of municipal solid waste compost (MSWC), cow dung (CD) and Urea (46\%, kg.ha-1) on weight of fresh and dry leaves of Jew's Mallow. They found that applying MSWC at $20 \mathrm{t}^{\mathrm{ha}} \mathrm{ha}^{-1} \mathrm{re}-$ corded the highest weight of fresh leaves (33.3 g.plant $\left.{ }^{-1}\right)$ followed by MSWC at $30 \mathrm{t} / \mathrm{ha}^{-1}$ (26.5 g.plant $\left.{ }^{-1}\right)$, CD 30 at t.ha ${ }^{-1}\left(21.5\right.$ g.plant $\left.{ }^{-1}\right)$ and urea at100 kg.ha- ${ }^{-1}\left(21.5\right.$ g.plant $\left.{ }^{-1}\right)$. In lettuce it was reported that $\mathrm{GA}_{3}$ significantly influenced the fresh weight of leaves per plant at 25, 35 and 45 days after planting (Akter, 2015). The author observed that the maximum weight of fresh leaves g.plant ${ }^{-1}$ $(30.35,89.61$ and $181.55 \mathrm{~g}$ at 25,35 and 45 DAS respectively) was recorded with application of $\mathrm{GA}_{3}$ at $20 \mathrm{ppm}$. Moreover, he observed that weight of fresh leaves g.plant ${ }^{-1}$ (17.74, 45.84 and $101.7 \mathrm{~g}$ at 25,35 and 45 DAS respectively) was recorded with control treatment. Sani (2104) reviewed that humic acid applications have positive effects on dry matter productivity and on nutrient mechanism of lettuce plant.

\section{Percentage net weight of leaves/ plant}

Percentages of net weight of plant leaves were significantly affected by sowing dates, ecotypess, foliar application and their interactions. Sowing Jew's Mallow plants on $15^{\text {th }}$ Feb. in 2015 and 2016 signifi- cantly increased percentages of net weight of plant leaves/ plant as compared to late planting dates. The ecotypes 'Assiut' revealed highest percentages of net weight of leaves/plant in both seasons, followed by the ecotypes 'Eskandarany', while ecotypes 'Aswan' registered the least percentages of net weight of leaves/plant (Table 5). The Application of $\mathrm{GA}_{3}$ at $0.25 \mathrm{mg} .1^{-1} \quad$ significantly increased percentage net weight of plant leaves in both seasons, followed by $0.5 \mathrm{mg} .1^{-}$ ${ }^{1} \mathrm{HA}+0.25 \mathrm{mg}^{-1} \mathrm{l}^{-1} \mathrm{GA}_{3}$ and $\mathrm{HA}$ at $0.5 \mathrm{mg} .1-1$, whereas the control treatment revealed the least percentages of net weight of plant leaves in 2016 . Significant interaction was observed between sowing dates, Jew's Mallow ecotypes and application of GA3 and HA with regard percentage net weight of plant leaves. Foliar application of GA3 at $0.25 \mathrm{mg} .1^{-1}$ extremely increased the percentages of net weight of plant leaves of the ecotypes 'Assiut' at the planting dates $15^{\text {th }}$ Feb. $2015(50.56 \%)$ and $15^{\text {th }}$ Feb. 2016 (51.45\%). Contrary, the ecotypes 'Aswan' recorded the least percentages of net weight of plant leaves under effects of foliar application of HA at $0.5 \mathrm{mg} .1^{-1}$ at late planting dates in both season (Table 5). The reasons for these observations can be attributed to the small number of leaves/plant, low weight of leaves/plant and partially elevated weight of plant produced by 'Aswan' ecotypes under foliar application of $\mathrm{HA}$ at $0.5 \mathrm{mg} \cdot \mathrm{l}^{-1}$. Contrary, adaptability of the ecotypes 'Assiut' to local climate increase effectiveness of foliar application of GA3 which result maximum number of leaves/plant, weight of leaves/plant, 
weight of plant and subsequently percentage of net weight of plant leaves. Yield of fresh weight of Jew's Mallow was significantly increased by foliar application of $\mathrm{GA}_{3}$ at $20 \mathrm{ppm}$ (Akter, 2015). In addition, it was reported that foliar application of humic acid significantly enhanced weight of leaves and weight of plant of lettuce (Sani, 2014). The Jew's Mallow ecotypes 'Mansoura' was reported to produce the maximum percentage of net weight of leaves/plant when cultivated in mid May as compared with other tested ecotypess and planting dates (Abdallah et al., 2010). The obtained results were partially in line with that observed by Wahba et al., (2003); Abd-Allah and Nasr (2005) and Rashwan (2011). They reported that late planting of Jew's Mallow $\left(1^{\text {st }}\right.$ June) significantly reduced percentage of net weight of plant leaves due to high temperature and day length (Wahba et al., 2003; Abd-Allah and Nasr 2005). Planting Jew's Mallow ecotypess on April $25^{\text {th }}$ result the highest plant heights, foliar yield and fresh and dry mass of plants (Rashwan (2011). It was recommended that mid May and Mid April are the promising planting dates for highest fresh leafy yield of Jew's Mallow ecotypess in Egypt (Abd-Allah et al. 2010).

\section{Foliage Yield (kg.plot ${ }^{-1}$ )}

As presented in Table (6), the early planting dates $15^{\text {th }}$ Feb. 2015 and 2016 result the highest foliage yield $\left(\mathrm{kg}^{\mathrm{p}}\right.$ plot $\left.^{-1}\right)$, whereas sowing dates $15^{\text {th }}$ Oct. significantly reduced the foliage yield in both seasons. Regarding the Jew's Mallow ecotypess, the results illustrated that ecotypes 'Assiut' produced the highest foliage yield since its extreme adaptability to the local dominant climate of the experimental location. The total foliage yield of ecotypes 'Assiut' were 19.89 and $17.45 \mathrm{~kg}$.plot ${ }^{-1}$ for planting dates $15^{\text {th }}$ Feb. 2015, $15^{\text {th }}$ Feb. 2016 respectively and 15.96, 14.74, kg.plot ${ }^{-1}$ for planting dates $15^{\text {th }}$ Oct. $2015,15^{\text {th }}$ Oct. 2016, respectively (Table 6). Least foliage yield were recorded for the ecotypes 'Aswan' at all planting dates. Concerning foliar applications the results revealed that spraying $\mathrm{GA}_{3}$ at $0.25 \mathrm{mg} .1^{-1}$ extremely increased total foliage yield of Jew's Mallow in both seasons, while the control treatment (without application of $\mathrm{GA}_{3}$ and HA) significantly reduced the total foliage yield (Table 6). Regarding interaction, the results showed that spraying plants of the ecotypes 'Assiut' with $\mathrm{GA}_{3}$ at $0.25 \mathrm{mg} .1^{-1}$ at planting dates $15^{\text {th }}$ Feb. result significant increase in foliage yield $\left(\mathrm{kg} \cdot \mathrm{plot}^{-1}\right)$ in both seasons (28.35 and 26.26 kg.plot ${ }^{-1}$ in $15^{\text {th }}$ Feb. 2015 and 2016, respectively). The ecotypes 'Aswan' recorded the least foliage yield under late planting conditions $\left(15^{\text {th }}\right.$ Oct.) and control treatment (without application of $\mathrm{GA}_{3}$ and HA) in both seasons $\left(10.07\right.$ and $8.03 \mathrm{~kg} \cdot$ plot $^{-1}$ in $15^{\text {th }}$ Oct. 2015 and $15^{\text {th }}$ Oct. 2016, respectively). Total yield of Jew's Mallow as all leafy vegetable dependent on yield attributes including number of leaves/plant, weight of plant leaves and percentage net weight of plant leaves (the ratio of weight of leaves: weight of plant). The Jew's Mallow ecotypes 'Assiut' is commonly known and continuously cultivated by farmers in Assiut regions several years ago. Its high growth and yield performance reflecting its consistent 
adaptability to dominant climates of Assiut regions. Based on this phenomenon the ecotypes 'Assiut' recorded highest values of yield attributes and subsequently total foliage yield (highest foliage yield (kg.plot ${ }^{-1}$ ). The obtained results were partially in line with that observed by Wahba et al., (2003); Abd-Allah and Nasr (2005) and Rashwan (2011). They reported that late planting of Jew's Mallow ( $1^{\text {st }}$ June) significantly reduced percentage of net weight of plant leaves due to high temperature and day length (Wahba et al. 2003; Abd-Allah and Nasr 2005). Planting Jew's Mallow ecotypess on April $25^{\text {th }}$ result the highest plant heights, foliar yield and fresh and dry mass of plants (Rashwan (2011). It was recommended that mid May and Mid April are the promising planting dates for highest fresh leafy yield of Jew's Mallow ecotypess in Egypt (AbdAllah et al., 2010 ).

$\mathrm{GA}_{3}$ and Humic acid play significant roles in plant growth and development including enhances growth activities to plant (Saini et al., 2017), stimulates stem elongation (Lee, 1990), and increases dry weight and yield (Deotale et al., 1998 and Maske et al., 1998). Limited information are available about the roles of $\mathrm{GA}_{3}$ and HA to enhance growth and yield of Jew's Mallow. In Indian mustard Sani et al., (2017) reported yield and quality contributing traits were maximum recorded with foliar sprayed of $\mathrm{GA}_{3}$ at $125 \mathrm{ppm}$ followed by foliar sprayed with $\mathrm{GA}_{3}$ at $90 \mathrm{ppm}$ over rest of the treatments including control. Fresh leaves yield of Jew's Mallow was significantly increased by foliar application of $\mathrm{GA}_{3}$ at 20 ppm (Akter, 2015). Moreover, foliar application of humic acid significantly enhanced yield attributes and total fresh yield of lettuce as compared to control treatment (Sani, 2014).

\section{Conclusion}

Out of the present study, it is recommended to grow the ecotype Assiut on feb. 15th and use foliar spray with $\mathrm{GA}_{3}$ at $0.25 \mathrm{mg} .1-1$ to produce an enhanced growth, yield and yield components.

\section{References}

Abd- Allah, S.A.M. and Nasr M.A. (2010). Effect of Sowing Date and Preservation Methods on some Egyptian Moloukhyia Genotypes (Corchorus olitorius, L.). Minufiya J. Agric. Res. Vol . 31 No. 4: 981995.

Abd-Allah, S.A.M. (2006). Variation and interrelationships of some Egyptian Moloukhyia genotypes (Corchorus olitorius L.). J. Agric. Sci. Mansoura Univ., 31(4): 2285 $-2296$.

Abdellatif, I.M.Y., Abdel-Ati Y.Y., Abdel-Mageed Y.T., Mohamed and Hassan A.H. (2017). Effect of Humic Acid on Growth and Productivity of tomato plants under heat stress. Journal of Horticultural Research, 25(2): 59-66.

Abdel-Razzak, H.S. and El-Sharkawy G.A. (2013). Effect of biofertilizer and humic acid applications on growth, yield, quality and storability of two garlic (Allium sativum L.) Cultivars. Asian Journal of Crop Science, 5: 48-64.

Akand H.M.d., Khairul Mazed H.E.M., Pulok A.I., Moonmoon J.F. and Partho S.G. (2015). Influence of different dose of nitrogen on the growth and yield of cabbage (Brassica oleracea var. capitata 1.). International Journal of Multid- 
isciplinary Research and Development 2015; 2(2): 11-14 .

Akter, T. (2015). Effect of gibberllic acid and spacing on growth and yield of lettuce (Lactuca sativa L.). MSc., Department of Horticulture, Sher-E-Bangla Agriculture University, Dhaka1207.

Arancon NQ, Edwards CA, Lee S, Byrne R. (2006). Effects of humic acids from vermicomposts on plant growth. European Journal of Soil Biology; 42: S65-S69.

Atiyeh RM, Lee S, Edwards CA, Arancon NQ, Metzger JD. (2002). The influence of humic acids derived from earthworm-processed organic wastes on plant growth. Bioresource Technology; 84:7-14.

Deotale, R.D., Maske V.G., Sorte M.V., Chimurkar B.S. and Yeme A.Z. (1998). Effect of $\mathrm{GA}_{3}$ and IAA on morpho-physiological parameters of soybean. J. Soils Crops, 8: 9194.

FAO. (2009). Food and Agriculture Organization of the United Nations. Jute Production Statistic. (www.fao.org).

Ghabbour, E.A. and Davies G. (2001). Humic Substances: Structures, Models and Functions. Royal Society of Chemistry, England, ISBN: 9780854048113, pp. 387.

Gomez, K.A. and A.A. Gomez.(1984). Statistical procedures for agricultural research. 2nd ed. John Wiley and Sons, New York.

Jamal Uddin AFM, Mehraj H, Taufique T, Ona AF, Parvin S (2014). Foliar application of gibberelic acid on growth and flowering of gerbera cultivars. Journal of Bioscience and Agriculture Research, 2(1), 52-58.

Khairul Mazed, H.E.M., Hasanuzzaman Akand M.d., Israt J.I., Moonmoon J.F., Hafizur Rahman M.D. (2015). Effect of gibberellic acid on the growth and yield of cabbage (Brassica oleracea var. capitata L.). International Journal of Applied Research, 1(4): 24-29.

Kumar, A., Biswas, T.K., Singh, N. and Lal, E.P. (2014). Effect of gibberellic acid on growth, quality and yield of tomato (Solanum lycopersicon Mill.). OSR Journal of Agriculture and Veterinary Science (IOSR-JAVS), 7: 28-30.

Kussow, W.R.(2002). Humate and $\mathrm{Hu}-$ mic Acid. June 2002 web issue of Horticulture

Update. http://aggiehorticulture.tamu.edu/e xtension/newsletters/hortupdate/ jun02/art4jun.htmg $>$ (October, 2007).

Lee, H.S. (1990). Effects of pre-sowing seed treatments with $\mathrm{GA}_{3}$ and IAA on flowering and yield components in groundnuts. Korean J. Crop Sci., 35: 1-9.

Maske, B.G., Detale R.D., Sorte N.B., Goramnagar H.B. and Chore C.N. (1998). Influence of $\mathrm{GA}_{3}$ and IAA on growth and yield contributing parameters of soybean. J. Soils Crops, 8: 20-21.

Netherlands/CTA, Wageningen, Netherlands. Harborne J.B., Baxter H., Moss G.P., (1999).

Ogunrinde A.T. and Fasinmirin J.T. (2011). Soil Moisture Distribution Pattern and Yield of Jute Mallow (Corchorus olitorius L.) under Three Different Soil Fertility Management. Proceedings of the Environmental Management Conference, Federal University of Agriculture, Abeokuta, Nigeria, 2011.

Rajpar1 I, Bhattil MB, Zia-ul-hassan1, Shah AN, Tunio SD. (2012). Humic acid improves growth, yield and oil content of Brassica campestris L. Pakistan Journal of Agriculture, Agricultural Engineering and Veterinary Sciences; 27:125133. 
Rashwan, A.M.A. (2011). Effect of sowing dates and plant spacing on growth and yield of some Jew's mallow ecotypess (corchorus olitorius L.) under South Valley condition. Assiut J. Agric. Sci., 42 No.2 (391-413).

Roy, R and Nasiruddin K. M. (2011). Effect of Different Level of $\mathrm{GA}_{3}$ on Growth and Yield of Cabbage. J. Environ. Sci. \& Natural Resources, 4(2): 79-82.

Sani, B. (2014). Foliar Application of Humic Acid on Plant Height in Canola. APCBEE Procedia (8): 82 -86 .

Saini, P.K., Yadav R.K. and Pratap M. (2017). Effect of Foliar Application of GA, on Yield and Quality of Indian Mustard [Brassica juncea (L.) Czern. \& Coss.] Under Sodic Soil. Int. J. Curr. Microbiol. App. Sci (2017) 6(12): 4156-4159.

Steel, R.G.D. and Torrie, J.H. (1982). Principles and procedures of statistics. A biometrical approach. McGraw-hill Book Co., 625 pp.

Tovihoudji, G.P., Djogbenou P.D.C., Akponikpe P.BI, Kpadonou E., Agbanga C.E. and Dagbenonbakin
D.G. (2015). Response of Jute Mallow (Corchorus olitorius L.) to organic manure and inorganic fertilizer on a ferruginous soil in North-eastern Benin. Journal of Applied Biosciences. 92:8610 8619.

Tsiakaras, G., Spyridon, A.P. and Khah, E.M. (2014). Effect of $\mathrm{GA}_{3}$ and nitrogen on yield and marketability of lettuce (Lactuca sativa L.). Australian Journal of crop science, 8(1): 127-132.

Vincent, E.R. and M. Yamaguchi. (1997). World Vegetables: Principles, Production, and Nutritive Values. $2^{\text {ed }}$, Department of Vegetables Crops. Uni. of California, Davis pp. 843. 849.

Yildirim EM. and Unay A. (2011). Effects of different fertilizations on Liriomyza trifolii in tomato. Afr. J. Agric. Res. 6(17): 4104-4107.

Wahba, R.M., S.M. Mansour, and E.A. Hassan. (2003). Vegetative yield and its components in Jew's mallow (Corchorus olitorius, L.) as affected by sowing date. J. Adv. Agric. Res. (8) 69-76. 
Table 1. Means of Plant height $(\mathrm{cm})$ of three Jew's Mallow ecotypes as affected by $\mathrm{GA}_{3}$ and HA foliar application and planting dates during 2015 and 2016.

\begin{tabular}{|c|c|c|c|c|c|}
\hline \multirow{3}{*}{$\begin{array}{l}\text { Jew's Mallow } \\
\text { ecotypes }\end{array}$} & \multirow{3}{*}{ Foliar applications } & \multicolumn{4}{|c|}{ Plant height (cm) } \\
\hline & & \multicolumn{2}{|c|}{2015} & \multicolumn{2}{|c|}{2016} \\
\hline & & $15^{\text {th }}$ Oct & $15^{\text {th }}$ Feb & $15^{\text {th }}$ Oct & $15^{\text {th }}$ Feb \\
\hline \multirow{4}{*}{ Eskandarany } & Unteated (T0) & $47.76 \mathrm{ef}$ & $62.50 \mathrm{ef}$ & $45.67 i$ & $48.46 \mathrm{~g}$ \\
\hline & $0.25 \mathrm{mg.l}^{-1} \mathrm{GA}_{3}$ (T1) & $70.03 \mathrm{bcd}$ & $78.34 \mathrm{cb}$ & $69.16 \mathrm{de}$ & $74.56 \mathrm{c}$ \\
\hline & $0.5 \mathrm{mg.} .^{-1}$ HA (T2) & $58.23 \mathrm{de}$ & $67.17 \mathrm{e}$ & $56.66 f g$ & $60.43 \mathrm{e}$ \\
\hline & $\begin{array}{ll}0.5 m g . l^{-1} & \text { HA } \\
0.25 \mathrm{mg}^{-1} \mathrm{I}^{-1} \mathrm{GA}_{3}(\mathrm{~T} 3)\end{array}$ & $62.26 \mathrm{~cd}$ & $70.28 \mathrm{de}$ & $60.40 \mathrm{f}$ & $65.22 \mathrm{dc}$ \\
\hline \multirow{4}{*}{ Assiut } & Unteated (T0) & 57.66efde & $64.57 \mathrm{e}$ & $51.76 \mathrm{gh}$ & $58.56 \mathrm{e}$ \\
\hline & $0.25 \mathrm{mg.l}^{-1} \mathrm{GA}_{3}(\mathrm{~T} 1)$ & $83.03 \mathrm{a}$ & $90.55 \mathrm{a}$ & $86.76 a$ & $92.67 \mathrm{a}$ \\
\hline & $0.5 \mathrm{mg} . \mathrm{I}^{-1} \mathrm{HA}(\mathrm{T} 2)$ & $74.86 a b c$ & $80.16 \mathrm{cb}$ & $74.33 \mathrm{~cd}$ & $80.18 b c$ \\
\hline & $\begin{array}{l}0.5 \mathrm{mg} . \mathrm{I}^{-1} \quad \text { HA } \\
0.25 \mathrm{mg}^{-\mathrm{I}^{-1}} \mathrm{GA}_{3}(\mathrm{~T} 3)\end{array}$ & $80.36 \mathrm{ab}$ & $85.45 \mathrm{ab}$ & $80.46 b$ & $86.45 \mathrm{abc}$ \\
\hline \multirow{4}{*}{ Aswan } & Unteated (T0) & $43.46 f$ & $55.67 \mathrm{f}$ & $49.37 \mathrm{hi}$ & $56.46 \mathrm{feg}$ \\
\hline & $0.25 \mathrm{mg.l}^{-1} \mathrm{GA}_{3}$ (T1) & $74.16 \mathrm{abc}$ & $80.57 \mathrm{cb}$ & $78.40 \mathrm{bc}$ & $68.35 \mathrm{dc}$ \\
\hline & $0.5 \mathrm{mg.I^{-1 }}$ HA (T2) & $70.03 \mathrm{bcd}$ & $78.46 \mathrm{cb}$ & $67.06 \mathrm{e}$ & $70.54 \mathrm{dc}$ \\
\hline & $\begin{array}{l}0.5 \mathrm{mg} . \mathrm{I}^{-1} \quad \text { HA } \\
0.25 \mathrm{mg}^{\circ} \mathrm{l}^{-1} \mathrm{GA}_{3}(\mathrm{~T} 3)\end{array}$ & $62.70 \mathrm{~cd}$ & $78.54 \mathrm{cb}$ & $68.60 \mathrm{e}$ & $70.00 \mathrm{dc}$ \\
\hline \multicolumn{6}{|c|}{ Mean Planting dates } \\
\hline & & $65.38 \mathrm{c}$ & $75.355 \mathrm{a}$ & $65.72 \mathrm{c}$ & $69.24 b$ \\
\hline \multicolumn{6}{|c|}{ Mean Jew's Mallow ecotypes } \\
\hline Eskandarany & & $59.57 b$ & $66.82 b$ & $57.97 \mathrm{~b}$ & $49.56 b$ \\
\hline Assiut & & $73.98 \mathrm{a}$ & $79.18 \mathrm{a}$ & $75.33 \mathrm{a}$ & $81.67 \mathrm{a}$ \\
\hline Aswan & & $62.59 \mathrm{~b}$ & $68.25 b$ & $65.85 \mathrm{ba}$ & $73.45 \mathrm{a}$ \\
\hline \multicolumn{6}{|c|}{ Mean foliar applications } \\
\hline \multicolumn{2}{|l|}{ Unteated (T0) } & $49.63 \mathrm{c}$ & $56.17 \mathrm{c}$ & $48.93 d$ & $50.45 \mathrm{~d}$ \\
\hline \multicolumn{2}{|c|}{$0.25 \mathrm{mg.l}^{-1}$ GA3 (T1) } & $76.74 \mathrm{a}$ & $78.20 \mathrm{a}$ & $73.11 \mathrm{a}$ & $82.57 \mathrm{a}$ \\
\hline \multicolumn{2}{|c|}{$0.5 \mathrm{mg.I^{-1 }}$ HA (T2) } & $67.71 \mathrm{~b}$ & $71.24 b$ & $66.02 c$ & $63.23 c$ \\
\hline \multicolumn{2}{|c|}{$0.5 \mathrm{mg.l}^{-1} \mathrm{HA}+0.25 \mathrm{mg.l}^{-1} \mathrm{GA}_{3}(\mathrm{~T} 3)$} & $68.44 \mathrm{ba}$ & $70.50 \mathrm{~b}$ & $69.82 \mathrm{~b}$ & $75.45 b$ \\
\hline
\end{tabular}

Means with different letters within columns are significantly different at 0.05 level of the probability using "Duncan's multiple range test". 
Table 2. Means of weight of plant (g) of three Jew's Mallow ecotypes as affected by GA3 and HA foliar application and planting dates during 2015 and 2016.

\begin{tabular}{|c|c|c|c|c|c|}
\hline \multirow{3}{*}{$\begin{array}{l}\text { Jew's Mallow } \\
\text { ecotypes }\end{array}$} & \multirow{3}{*}{ Foliar applications } & \multicolumn{4}{|c|}{ weight of plant (g) } \\
\hline & & \multicolumn{2}{|c|}{2015} & \multicolumn{2}{|c|}{2016} \\
\hline & & $15^{\text {th }}$ Oct & $15^{\text {th }}$ Feb & $15^{\text {th }}$ Oct & $15^{\text {th }}$ Feb \\
\hline \multirow{4}{*}{ Eskandarany } & Unteated (T0) & $47.26 \mathrm{fg}$ & $54.23 \mathrm{gh}$ & $43.67 \mathrm{j}$ & $50.34 \mathrm{~h}$ \\
\hline & $0.25 \mathrm{mg.I^{-1 }}$ GA3 (T1) & $71.46 \mathrm{bcd}$ & $82.56 b c$ & $75.26 \mathrm{~cd}$ & $78.45 \mathrm{~cd}$ \\
\hline & $0.5 \mathrm{mg.l}^{-1} \mathrm{HA}(\mathrm{T} 2)$ & $65.40 \mathrm{de}$ & $72.45 \mathrm{ef}$ & $60.33 \mathrm{gh}$ & $66.46 \mathrm{fg}$ \\
\hline & $\begin{array}{l}0.5 \mathrm{mg} . \mathrm{I}^{-1} \text { HA } \\
0.25 \mathrm{mg} . \mathrm{I}^{-1} \text { GA3 (T3) }\end{array}$ & $72.97 b c$ & $80.45 b c$ & $71.37 \mathrm{def}$ & $76.23 \mathrm{cde}$ \\
\hline \multirow{4}{*}{ Assiut } & Unteated (T0) & $51.13 f$ & $49.34 \mathrm{~h}$ & $57.03 \mathrm{hi}$ & $60.59 \mathrm{~g}$ \\
\hline & $0.25 \mathrm{mg.l}^{-1} \mathrm{GA}_{3}$ (T1) & $81.52 \mathrm{a}$ & $95.37 \mathrm{a}$ & $88.06 \mathrm{a}$ & $93.35 \mathrm{a}$ \\
\hline & $0.5 \mathrm{mg} . \mathrm{I}^{-1} \mathrm{HA}$ (T2) & $67.26 \mathrm{cde}$ & $71.65 \mathrm{ef}$ & $60.00 \mathrm{gh}$ & $74.05 \mathrm{de}$ \\
\hline & $\begin{array}{l}0.5 \mathrm{mg} . \mathrm{l}^{-1} \quad \mathrm{HA} \\
0.25 \mathrm{mg}^{-\mathrm{I}^{-1}} \mathrm{GA}_{3}(\mathrm{~T} 3)\end{array}$ & $75.83 \mathrm{ab}$ & $87.34 b$ & $81.50 \mathrm{bc}$ & $90.68 \mathrm{a}$ \\
\hline \multirow{4}{*}{ Aswan } & Unteated (T0) & $44.63 \mathrm{~g}$ & $50.35 \mathrm{gh}$ & $51.50 \mathrm{i}$ & $57.48 \mathrm{jg}$ \\
\hline & $0.25 \mathrm{mg.l}^{-1} \mathrm{GA}_{3}$ (T1) & $73.36 \mathrm{bc}$ & $76.62 \mathrm{de}$ & $67.00 \mathrm{f}$ & $80.34 \mathrm{bcd}$ \\
\hline & $0.5 \mathrm{mg} . \mathrm{I}^{-1} \mathrm{HA}(\mathrm{T} 2)$ & $61.57 \mathrm{e}$ & $65.23 \mathrm{f}$ & $66.83 \mathrm{f}$ & $69.48 \mathrm{ef}$ \\
\hline & $\begin{array}{l}0.5 \mathrm{mg} . \mathrm{l}^{-1} \quad \text { HA } \\
0.25 \mathrm{mg}^{-1} \mathrm{l}^{-1} \mathrm{GA}_{3}(\mathrm{~T} 3)\end{array}$ & $64.57 \mathrm{e}$ & $68.45 \mathrm{f}$ & $68.00 \mathrm{ef}$ & $70.45 \mathrm{de}$ \\
\hline \multicolumn{6}{|c|}{ Mean Planting dates } \\
\hline & & $64.75 b$ & $71.17 \mathrm{a}$ & $65.88 \mathrm{~b}$ & $72.32 \mathrm{a}$ \\
\hline \multicolumn{6}{|c|}{ Mean Jew's Mallow ecotypes } \\
\hline Eskandarany & & $64.27 \mathrm{~b}$ & $70.02 b$ & $62.66 b$ & $69.56 c$ \\
\hline Assiut & & $68.93 a$ & $76.59 \mathrm{a}$ & $71.54 \mathrm{a}$ & $74.34 \mathrm{a}$ \\
\hline Aswan & & $61.03 \mathrm{c}$ & $67.17 \mathrm{c}$ & $61.71 b$ & $66.25 b$ \\
\hline \multicolumn{6}{|c|}{ Mean foliar applications } \\
\hline \multicolumn{2}{|l|}{ Unteated (T0) } & $47.67 \mathrm{c}$ & $60.34 \mathrm{c}$ & $51.07 \mathrm{c}$ & $64.23 \mathrm{~d}$ \\
\hline \multicolumn{2}{|c|}{$0.25 \mathrm{mg.l}^{-1}$ GA3 (T1) } & $75.45 a$ & $79.36 \mathrm{a}$ & $77.94 a$ & $85.46 \mathrm{a}$ \\
\hline \multicolumn{2}{|c|}{$0.5 \mathrm{mg.l}^{-1} \mathrm{HA}(\mathrm{T} 2)$} & $64.74 d$ & $73.89 b$ & $63.05 b$ & $70.56 \mathrm{c}$ \\
\hline \multicolumn{2}{|c|}{ 0.5mg. $.^{-1} \mathrm{HA}+0.25 \mathrm{mg.I^{-1 }}$ GA $_{3}(\mathrm{~T} 3)$} & $71.12 b$ & $74.18 b$ & $73.95 \mathrm{a}$ & $80.45 b$ \\
\hline
\end{tabular}

Means with different letters within columns are significantly different at 0.05 level of the probability using "Duncan's multiple range test". 
Table 3. Means of number of leaves/plants of three Jew's Mallow ecotypes as affected by $\mathrm{GA}_{3}$ and $\mathrm{HA}$ foliar application and planting dates during 2015 and 2016.

\begin{tabular}{|c|c|c|c|c|c|}
\hline \multirow{3}{*}{$\begin{array}{l}\text { Jew's Mallow } \\
\text { ecotypes }\end{array}$} & \multirow{3}{*}{ Foliar applications } & \multicolumn{4}{|c|}{ no. of leaves/plant } \\
\hline & & \multicolumn{2}{|c|}{2015} & \multicolumn{2}{|c|}{2016} \\
\hline & & $15^{\text {th }}$ Oct & $15^{\text {th }}$ Feb & $15^{\text {th }}$ Oct & $15^{\text {th }}$ Feb \\
\hline \multirow{4}{*}{ Eskandarany } & Unteated (T0) & $28.33 \mathrm{fg}$ & $30.83 \mathrm{~g}$ & $22.70 \mathrm{e}$ & $26.78 \mathrm{e}$ \\
\hline & $0.25 \mathrm{mg.l}^{-1} \mathrm{GA}_{3}$ (T1) & $55.00 \mathrm{abc}$ & $62.45 b$ & $51.00 \mathrm{ab}$ & $57.34 \mathrm{ab}$ \\
\hline & $0.5 \mathrm{mg.} .{ }^{-1}$ HA (T2) & $47.70 \mathrm{~cd}$ & $51.44 \mathrm{~cd}$ & $39.70 \mathrm{c}$ & $45.16 \mathrm{~cd}$ \\
\hline & $\begin{array}{l}0.5 \mathrm{mg} . \mathrm{I}^{-1} \quad \text { HA } \\
0.25 \mathrm{mg}^{\circ} \mathrm{I}^{-1} \mathrm{GA}_{3}(\mathrm{~T} 3)\end{array}$ & $50.34 b$ & $67.16 \mathrm{ab}$ & $48.67 \mathrm{ab}$ & $57.22 b$ \\
\hline \multirow{4}{*}{ Assiut } & Unteated (T0) & $32.00 \mathrm{ef}$ & $40.34 \mathrm{f}$ & $27.33 \mathrm{de}$ & $37.12 \mathrm{~cd}$ \\
\hline & $0.25 \mathrm{mg.l}^{-1} \mathrm{GA}_{3}$ (T1) & $58.67 \mathrm{a}$ & $70.08 \mathrm{a}$ & $53.01 \mathrm{a}$ & $62.00 \mathrm{a}$ \\
\hline & $0.5 \mathrm{mg.l^{-1 }}$ HA (T2) & $44.66 \mathrm{~d}$ & $48.22 \mathrm{de}$ & $37.33 c$ & $45.34 \mathrm{~cd}$ \\
\hline & $\begin{array}{l}0.5 \mathrm{mg} . \mathrm{l}^{-1} \\
0.25 \mathrm{mg}^{-1} \mathrm{l}^{-1} \mathrm{GA}_{3}(\mathrm{~T} 3)\end{array}+$ & $51.00 \mathrm{~b}$ & $61.50 \mathrm{~b}$ & $46.00 \mathrm{~b}$ & $54.23 b$ \\
\hline \multirow{4}{*}{ Aswan } & Unteated (T0) & $25.33 \mathrm{~g}$ & $33.76 \mathrm{~g}$ & $22.40 \mathrm{e}$ & $32.14 \mathrm{de}$ \\
\hline & $0.25 \mathrm{mg.l}^{-1} \mathrm{GA}_{3}$ (T1) & $37.33 \mathrm{e}$ & $42.45 \mathrm{ef}$ & $31.40 \mathrm{~d}$ & $45.30 \mathrm{ab}$ \\
\hline & $0.5 \mathrm{mg} . \mathrm{l}^{-1} \mathrm{HA}(\mathrm{T} 2)$ & $34.70 \mathrm{e}$ & $47.23 \mathrm{de}$ & $23.67 \mathrm{e}$ & $48.19 \mathrm{~cd}$ \\
\hline & $\begin{array}{l}0.5 \mathrm{mg} . \mathrm{l}^{-1} \mathrm{HA} \\
0.25 \mathrm{mg}^{-1} \mathrm{l}^{-1} \mathrm{GA}_{3}(\mathrm{~T} 3)\end{array}$ & $34.33 \mathrm{e}$ & $40.45 f$ & 26.33de & $43.12 \mathrm{~cd}$ \\
\hline \multicolumn{6}{|c|}{ Mean Planting dates } \\
\hline & & $41.62 \mathrm{c}$ & $49.66 \mathrm{a}$ & $35.79 \mathrm{~d}$ & $46.16 \mathrm{~b}$ \\
\hline \multicolumn{6}{|c|}{ Mean Jew's Mallow ecotypes } \\
\hline Eskandarany & & $32.33 b$ & $45.33 b$ & $34.50 \mathrm{~b}$ & $51.34 \mathrm{~b}$ \\
\hline Assiut & & $46.58 \mathrm{a}$ & $51.58 \mathrm{a}$ & $40.91 \mathrm{a}$ & $55.82 \mathrm{a}$ \\
\hline Aswan & & $27.91 \mathrm{c}$ & $32.91 \mathrm{c}$ & $25.91 \mathrm{c}$ & $47.34 c$ \\
\hline \multicolumn{6}{|c|}{ Mean foliar applications } \\
\hline \multicolumn{2}{|l|}{ Unteated (T0) } & $28.55 \mathrm{c}$ & $32.45 d$ & $24.11 \mathrm{~d}$ & $34.80 \mathrm{~d}$ \\
\hline \multicolumn{2}{|c|}{$0.25 \mathrm{mg.l}^{-1} \mathrm{GA}_{3}$ (T1) } & $50.33 a$ & $61.24 \mathrm{a}$ & $45.11 \mathrm{a}$ & 52.56 \\
\hline \multicolumn{2}{|c|}{$0.5 \mathrm{mg.I^{-1 }}$ HA (T2) } & $42.33 b$ & $47.23 \mathrm{cb}$ & $33.55 \mathrm{c}$ & $50.06 \mathrm{c}$ \\
\hline \multicolumn{2}{|c|}{ 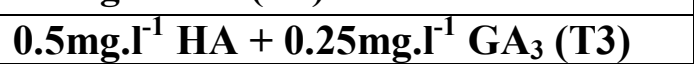 } & $45.22 b$ & $51.45 \mathrm{~b}$ & $40.33 b$ & $56.45 b$ \\
\hline
\end{tabular}

Means with different letters within columns are significantly different at 0.05 level of the probability using "Duncan's multiple range test". 
Table 4. Means weight of plant leaves (g) of three Jew's Mallow ecotypes as affected by GA3 and HA foliar application and planting dates during 2015 and 2016.

\begin{tabular}{|c|c|c|c|c|c|}
\hline \multirow{3}{*}{$\begin{array}{l}\text { Jew's Mallow } \\
\text { ecotypes }\end{array}$} & \multirow{3}{*}{ Foliar applications } & \multicolumn{4}{|c|}{ weight of leaves/plant (g) } \\
\hline & & \multicolumn{2}{|c|}{2015} & \multicolumn{2}{|c|}{2016} \\
\hline & & $15^{\text {th }}$ Oct & $15^{\text {th }}$ Feb & $15^{\text {th }}$ Oct & $15^{\text {th }}$ Feb \\
\hline \multirow{4}{*}{ Eskandarany } & Unteated (T0) & $14.00 \mathrm{~g}$ & $16.45 \mathrm{~h}$ & $10.60 \mathrm{~g}$ & 15.68 \\
\hline & $0.25 \mathrm{mg.l}^{-1} \mathrm{GA}_{3}$ (T1) & $24.10 b c$ & $32.67 \mathrm{bc}$ & $23.27 \mathrm{bc}$ & $29.34 \mathrm{cb}$ \\
\hline & $0.5 \mathrm{mg.} .{ }^{-1}$ HA (T2) & $18.90 \mathrm{ef}$ & $23.54 \mathrm{fg}$ & $15.27 \mathrm{e}$ & $19.36 \mathrm{f}$ \\
\hline & $\begin{array}{lll}0.5 \mathrm{mg} . I^{-1} & \text { HA } \\
0.25 \mathrm{mg}^{-1} \mathrm{I}^{-1} & \mathrm{GA}_{3}(\mathrm{~T} 3)\end{array}$ & $23.08 \mathrm{~cd}$ & $30.43 \mathrm{cdh}$ & $21.27 \mathrm{~cd}$ & $28.49 \mathrm{db}$ \\
\hline \multirow{4}{*}{ Assiut } & Unteated (T0) & $16.73 \mathrm{fg}$ & $22.67 \mathrm{~g}$ & $13.89 \mathrm{ef}$ & $19.68 \mathrm{f}$ \\
\hline & $0.25 \mathrm{mg.l}^{-1} \mathrm{GA}_{3}$ (T1) & $34.70 \mathrm{a}$ & $45.86 \mathrm{a}$ & $38.22 \mathrm{a}$ & $50.00 \mathrm{a}$ \\
\hline & $0.5 \mathrm{mg.l}^{-1} \mathrm{HA}(\mathrm{T} 2)$ & $23.27 \mathrm{c}$ & $30.45 \mathrm{cdh}$ & $19.35 d$ & $28.43 \mathrm{db}$ \\
\hline & $\begin{array}{lcl}0.5 \mathrm{mg} . I^{-1} & \text { HA } \\
0.25 \mathrm{mg.l}^{-1} & \mathrm{GA}_{3}(\mathrm{~T} 3)\end{array}$ & $27.67 b$ & $34.23 b c$ & $25.67 b$ & $30.34 b$ \\
\hline \multirow{4}{*}{ Aswan } & Unteated (T0) & $13.97 \mathrm{~g}$ & $18.67 \mathrm{~h}$ & $11.78 \mathrm{fg}$ & $20.68 \mathrm{ef}$ \\
\hline & $0.25 \mathrm{mg.l}^{-1} \mathrm{GA}_{3}$ (T1) & $21.80 \mathrm{cde}$ & $29.24 \mathrm{dfh}$ & $20.02 d$ & $32.56 \mathrm{~b}$ \\
\hline & $0.5 \mathrm{mg.} .^{-1} \mathrm{HA}(\mathrm{T} 2)$ & $17.56 \mathrm{fg}$ & $23.34 \mathrm{fg}$ & $11.59 \mathrm{fg}$ & $19.86 \mathrm{f}$ \\
\hline & $\begin{array}{lll}0.5 \mathrm{mg} . I^{-1} & \text { HA } \\
0.25 \mathrm{mg.l}^{-1} & \mathrm{GA}_{3}(\mathrm{~T} 3)\end{array}+$ & $19.33 \mathrm{def}$ & $27.56 \mathrm{ef}$ & $15.57 \mathrm{e}$ & $22.46 \mathrm{ef}$ \\
\hline \multicolumn{6}{|c|}{ Mean Planting dates } \\
\hline & & $21.26 \mathrm{c}$ & $27.92 \mathrm{a}$ & $18.87 \mathrm{~d}$ & $26.40 \mathrm{a}$ \\
\hline \multicolumn{6}{|c|}{ Mean Jew's Mallow ecotypes } \\
\hline Eskandarany & & $20.02 b$ & $25.60 \mathrm{~b}$ & $17.60 \mathrm{~b}$ & $21.00 \mathrm{~b}$ \\
\hline Assiut & & $25.59 \mathrm{a}$ & $32.45 \mathrm{a}$ & $24.28 \mathrm{a}$ & $34.65 \mathrm{a}$ \\
\hline Aswan & & $18.17 \mathrm{~b}$ & $24.33 b$ & $14.74 b$ & $21.35 b$ \\
\hline \multicolumn{6}{|c|}{ Mean foliar applications } \\
\hline Unteated (T0) & & $14.90 \mathrm{~d}$ & $19.34 d$ & $12.09 \mathrm{~d}$ & $18.59 \mathrm{~d}$ \\
\hline $0.25 \mathrm{mg.l}^{-1} \mathrm{GA}_{3}$ & (T1) & $26.86 \mathrm{a}$ & $35.00 \mathrm{a}$ & $27.17 \mathrm{a}$ & $40.33 a$ \\
\hline $0.5 \mathrm{mg} . \mathrm{I}^{-1} \mathrm{HA}($ & Г2) & $19.91 \mathrm{c}$ & $27.48 \mathrm{c}$ & $15.40 \mathrm{c}$ & $24.35 \mathrm{c}$ \\
\hline $0.5 \mathrm{mg} . \mathrm{I}^{-1} \mathrm{HA}+$ & $0.25 \mathrm{mg.l}^{-1} \mathrm{GA}_{3}$ (T3) & $23.36 \mathrm{~b}$ & $31.08 \mathrm{~b}$ & $20.84 b$ & $29.33 b$ \\
\hline
\end{tabular}

Means with different letters within columns are significantly different at 0.05 level of the probability using "Duncan's multiple range test". 
Table 5. Means of percentage net weight of plant leaves of three Jew's Mallow ecotypes as affected by GA3 and HA foliar application and planting dates during 2015 and 2016.

\begin{tabular}{|c|c|c|c|c|c|}
\hline \multirow{3}{*}{$\begin{array}{l}\text { Jew's Mallow } \\
\text { ecotypes }\end{array}$} & \multirow{3}{*}{ Foliar applications } & \multicolumn{4}{|c|}{$\%$ net weight of plant leaves } \\
\hline & & \multicolumn{2}{|c|}{2015} & \multicolumn{2}{|c|}{2016} \\
\hline & & $15^{\text {th }}$ Oct & $15^{\text {th }}$ Feb & $15^{\text {th }}$ Oct & $15^{\text {th }}$ Feb \\
\hline \multirow{4}{*}{ Eskandarany } & Unteated (T0) & $29.61 \mathrm{De}$ & $34.45 \mathrm{e}$ & $22.00 \mathrm{efg}$ & $27.17 \mathrm{~g}$ \\
\hline & $0.25 \mathrm{mg.l}^{-1}$ GA3 (T1) & $33.74 b c$ & $40.36 b$ & $32.25 b$ & $37.13 \mathrm{cbd}$ \\
\hline & $0.5 \mathrm{mg} . \mathrm{I}^{-1} \mathrm{HA}$ (T2) & $29.70 \mathrm{de}$ & $37.18 \mathrm{~cd}$ & $25.45 \mathrm{de}$ & $32.33 \mathrm{edfg}$ \\
\hline & $\begin{array}{l}0.5 \mathrm{mg} . \mathrm{I}^{-1} \text { HA } \\
0.25 \mathrm{mg} . \mathrm{I}^{-1} \text { GA3 (T3) }\end{array}$ & $31.56 \mathrm{bcde}$ & $35.67 \mathrm{de}$ & $30.73 b c$ & $40.55 b$ \\
\hline \multirow{4}{*}{ Assiut } & Unteated (T0) & $32.82 \mathrm{bcd}$ & $36.78 \mathrm{cde}$ & $27.64 \mathrm{~cd}$ & $33.18 \mathrm{edfg}$ \\
\hline & 0.25mg..$^{-1}$ GA3 (T1) & $41.68 \mathrm{a}$ & $50.56 \mathrm{a}$ & $44.95 a$ & $51.45 \mathrm{a}$ \\
\hline & $0.5 \mathrm{mg} . \mathrm{l}^{-1} \mathrm{HA}(\mathrm{T} 2)$ & $32.84 \mathrm{bcd}$ & $39.05 \mathrm{~cd}$ & $30.25 b c$ & $36.28 \mathrm{cbd}$ \\
\hline & $\begin{array}{l}0.5 \mathrm{mg} . \mathrm{l}^{-1} \text { HA } \\
0.25 \mathrm{mg}^{-1} \mathrm{I}^{-1} \text { GA3 (T3) }\end{array}$ & $34.94 b$ & $40.23 b c$ & $31.52 b c$ & $35.67 d$ \\
\hline \multirow{4}{*}{ Aswan } & Unteated (T0) & $31.08 \mathrm{bcde}$ & $40.19 b c$ & $20.94 \mathrm{fg}$ & $32.26 \mathrm{edfg}$ \\
\hline & $0.25 \mathrm{mg.l}^{-1}$ GA3 (T1) & 29.60de & $34.23 \mathrm{e}$ & $30.08 \mathrm{bc}$ & $37.58 \mathrm{cbd}$ \\
\hline & $0.5 \mathrm{mg} . \mathrm{I}^{-1} \mathrm{HA}(\mathrm{T} 2)$ & $28.31 \mathrm{e}$ & $36.10 \mathrm{cde}$ & $18.06 \mathrm{~g}$ & $28.90 \mathrm{~g}$ \\
\hline & $\begin{array}{l}0.5 \mathrm{mg} . .^{-1} \text { HA } \\
0.25 \mathrm{mg}^{-1} \mathrm{I}^{-1} \text { GA3 }(\mathrm{T3})\end{array}$ & $29.93 \mathrm{cde}$ & $34.25 \mathrm{e}$ & $25.22 \mathrm{def}$ & $31.45 \mathrm{fg}$ \\
\hline \multicolumn{6}{|c|}{ Mean Planting dates } \\
\hline & & $32.15 \mathrm{c}$ & $38.25 \mathrm{a}$ & $28.25 b$ & $35.32 \mathrm{a}$ \\
\hline \multicolumn{6}{|c|}{ Mean Jew's Mallow ecotypes } \\
\hline Eskandarany & & $31.15 b$ & $37.56 b$ & $27.66 \mathrm{~b}$ & $35.45 b$ \\
\hline Assiut & & $35.57 \mathrm{a}$ & $40.23 a$ & $33.59 \mathrm{a}$ & $38.18 \mathrm{a}$ \\
\hline Aswan & & $29.73 b$ & $36.58 b$ & $23.57 \mathrm{c}$ & $30.87 \mathrm{c}$ \\
\hline \multicolumn{6}{|c|}{ Mean foliar applications } \\
\hline Unteated (T0) & & $31.17 \mathrm{~b}$ & $38.27 b$ & $23.59 \mathrm{c}$ & $32.13 d$ \\
\hline $0.25 \mathrm{mg} \mathrm{I}^{-1} \mathrm{GA} 3$ & (T1) & $35.01 \mathrm{a}$ & $41.12 \mathrm{a}$ & $35.76 a$ & $41.29 \mathrm{a}$ \\
\hline $0.5 \mathrm{mg} . \mathrm{I}^{-1} \mathrm{HA}($ & Г2) & $30.28 b$ & $33.35 \mathrm{c}$ & $24.59 \mathrm{c}$ & $34.56 \mathrm{c}$ \\
\hline $0.5 \mathrm{mg}^{-\mathrm{I}^{-1}} \mathrm{HA}+$ & $0.25 \mathrm{mg.l}^{-1}$ GA3 (T3) & $32.14 \mathrm{~b}$ & $36.40 \mathrm{~b}$ & $29.16 \mathrm{~b}$ & $35.78 \mathrm{~b}$ \\
\hline
\end{tabular}

Means with different letters within columns are significantly different at 0.05 level of the probability using "Duncan's multiple range test". 
Table 6. Means of foliage yield $\left(\mathrm{kg}\right.$ plot $\left.^{-1}\right)$ of three Jew's Mallow ecotypes as affected by GA3 and HA foliar application and planting dates during 2015 and 2016.

\begin{tabular}{|c|c|c|c|c|c|}
\hline \multirow{3}{*}{$\begin{array}{l}\text { Jew's Mallow } \\
\text { ecotypes }\end{array}$} & \multirow{3}{*}{ Foliar applications } & \multicolumn{4}{|c|}{ Foliage Yield (kg/plot) } \\
\hline & & \multicolumn{2}{|c|}{2015} & \multicolumn{2}{|c|}{2016} \\
\hline & & $15^{\text {th }}$ Oct & $15^{\text {th }}$ Feb & $15^{\text {th }}$ Oct & $15^{\text {th }}$ Feb \\
\hline \multirow{4}{*}{ Eskandarany } & Unteated (T0) & $12.11 \mathrm{c}$ & $17.34 d$ & $9.01 \mathrm{de}$ & $14.91 \mathrm{fg}$ \\
\hline & 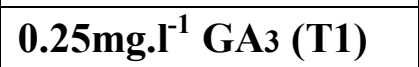 & $16.16 \mathrm{~b}$ & $21.56 b$ & $15.76 b$ & $19.34 \mathrm{bc}$ \\
\hline & $0.5 \mathrm{mg.l}^{-1} \mathrm{HA}(\mathrm{T} 2)$ & $14.87 \mathrm{~b}$ & $19.27 \mathrm{c}$ & $11.98 \mathrm{~cd}$ & $18.69 b c$ \\
\hline & $\begin{array}{l}0.5 \mathrm{mg} . \mathrm{l}^{-1} \text { HA } \\
0.25 \mathrm{mg} . \mathrm{I}^{-1} \text { GA3 (T3) }\end{array}$ & $12.19 \mathrm{c}$ & $17.76 \mathrm{~d}$ & $12.09 \mathrm{~cd}$ & $18.08 \mathrm{c}$ \\
\hline \multirow{4}{*}{ Assiut } & Unteated (T0) & $11.83 \mathrm{~cd}$ & $19.32 \mathrm{c}$ & 9.78de & $15.45 \mathrm{ef}$ \\
\hline & 0.25mg..$^{-1}$ GA3 (T1) & $19.06 \mathrm{a}$ & $28.35 \mathrm{a}$ & $21.24 \mathrm{a}$ & $26.26 \mathrm{a}$ \\
\hline & $0.5 \mathrm{mg} . \mathrm{l}^{-1} \mathrm{HA}(\mathrm{T} 2)$ & $13.24 \mathrm{c}$ & $16.56 \mathrm{edf}$ & $11.99 \mathrm{~cd}$ & $14.67 \mathrm{fg}$ \\
\hline & $\begin{array}{l}0.5 \mathrm{mg} . \mathrm{l}^{-1} \text { HA } \\
0.25 \mathrm{mg} . \mathrm{I}^{-1} \text { GA3 (T3) }\end{array}$ & $15.71 b$ & $19.23 \mathrm{c}$ & $14.87 \mathrm{bc}$ & 16.46de \\
\hline \multirow{4}{*}{ Aswan } & Unteated (T0) & $10.07 \mathrm{e}$ & $15.45 \mathrm{gh}$ & $8.03 \mathrm{e}$ & $12.39 \mathrm{~h}$ \\
\hline & $0.25 \mathrm{mg}^{-1} \mathrm{l}^{-1} \mathrm{GA3}$ (T1) & $12.94 \mathrm{c}$ & $16.23 \mathrm{fg}$ & $12.11 \mathrm{~cd}$ & $15.55 \mathrm{ef}$ \\
\hline & $0.5 \mathrm{mg.I^{-1 }}$ HA (T2) & $11.85 \mathrm{~cd}$ & $15.37 \mathrm{gh}$ & $8.23 \mathrm{e}$ & $12.70 \mathrm{gh}$ \\
\hline & $\begin{array}{l}0.5 \mathrm{mg} . \mathrm{l}^{-1} \text { HA } \\
0.25 \mathrm{mg} . \mathrm{I}^{-1} \text { GA3 (T3) }\end{array}$ & $10.33 \mathrm{de}$ & $14.56 \mathrm{~h}$ & $8.53 \mathrm{e}$ & $13.24 \mathrm{gh}$ \\
\hline \multicolumn{6}{|c|}{ Mean Planting dates } \\
\hline & & $13.36 \mathrm{~b}$ & $18.41 \mathrm{a}$ & $11.96 \mathrm{c}$ & $16.47 \mathrm{a}$ \\
\hline \multicolumn{6}{|c|}{ Mean Jew's Mallow ecotypes } \\
\hline Eskandarany & & $13.83 \mathrm{a}$ & $17.58 \mathrm{~b}$ & $12.21 \mathrm{a}$ & $15.06 \mathrm{~b}$ \\
\hline Assiut & & $15.96 \mathrm{a}$ & $19.89 \mathrm{a}$ & $14.47 \mathrm{a}$ & $17.45 \mathrm{a}$ \\
\hline Aswan & & $11.30 \mathrm{~b}$ & $15.44 \mathrm{c}$ & $9.24 b$ & $12.35 \mathrm{c}$ \\
\hline \multicolumn{6}{|c|}{ Mean foliar applications } \\
\hline \multicolumn{2}{|l|}{ Unteated (T0) } & $11.34 \mathrm{c}$ & $13.67 \mathrm{c}$ & $8.94 \mathrm{c}$ & $12.45 \mathrm{c}$ \\
\hline \multicolumn{2}{|c|}{$0.25 \mathrm{mg.l}^{-1}$ GA3 (T1) } & $16.05 \mathrm{a}$ & $20.34 \mathrm{a}$ & $16.37 \mathrm{a}$ & $19.24 \mathrm{a}$ \\
\hline \multicolumn{2}{|c|}{$0.5 \mathrm{mg.I}^{-1}$ HA (T2) } & $13.32 b$ & $17.58 b$ & $10.75 \mathrm{cb}$ & $15.46 \mathrm{~b}$ \\
\hline \multicolumn{2}{|c|}{ 0.5mg. ${ }^{-1}$ HA + 0.25mg..$^{-1}$ GA3 (T3) } & $12.74 \mathrm{~b}$ & $16.90 \mathrm{~b}$ & $11.83 \mathrm{~b}$ & $15.34 \mathrm{~b}$ \\
\hline
\end{tabular}

Means with different letters within columns are significantly different at 0.05 level of the probability using "Duncan's multiple range test". 
نمو ومحصول بعض الطرز البيئية من الملوخية وتأثرهما بميعاد الزراعة والرش الورقي

بحمضي الجبريلليك و الهيوميك

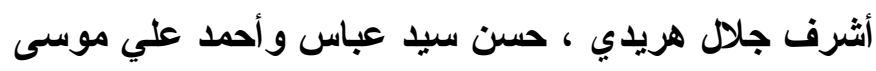

قسم الخضر -كلية الزر اعة-جامعة أسيوط-أسيوط

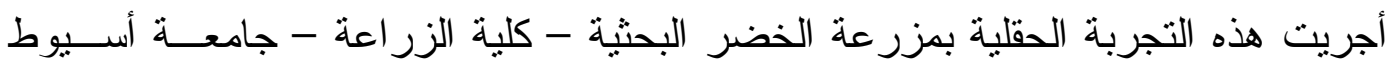

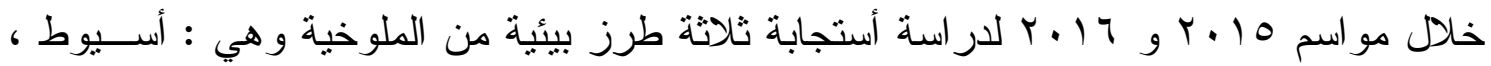

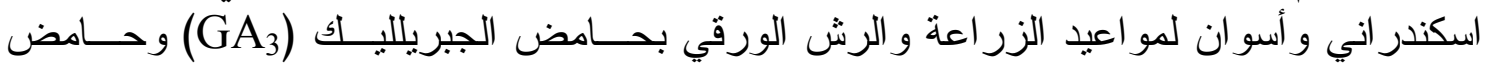

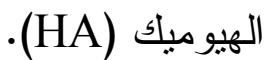

زرعت الطرز البيئية الثلاثة في 10 فبر اير و 10 أكتوبر في كلا من عامى الدراســـة ،

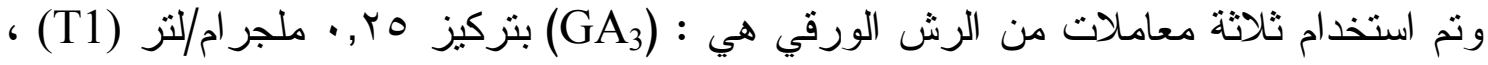

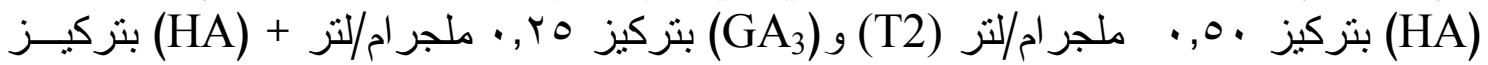

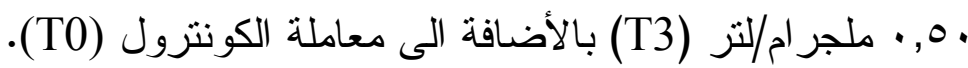

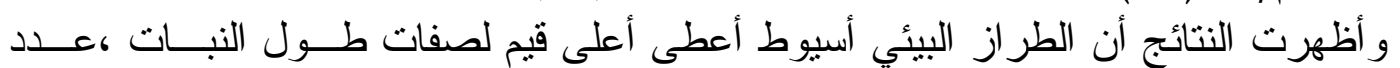

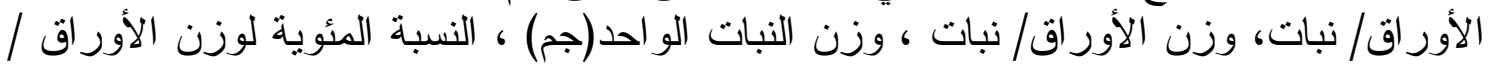

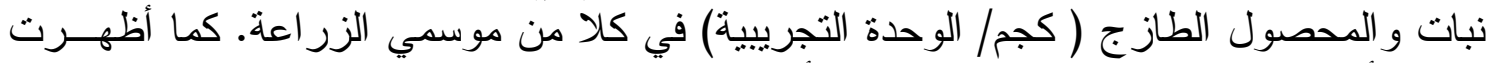

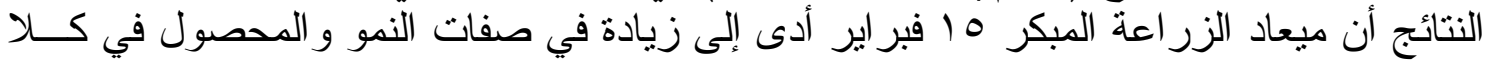

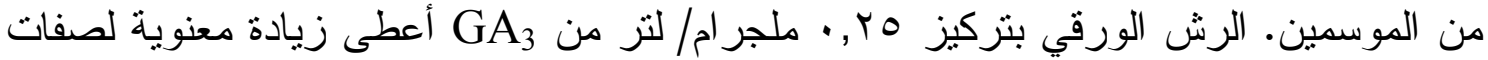

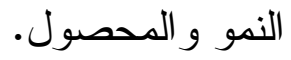

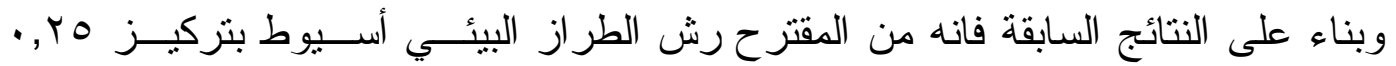

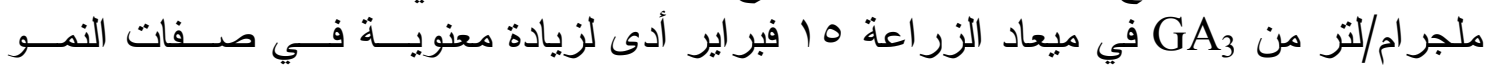
و المحصول ومكوناتة في كلا من موسمي الزر اعة اعن. 